\title{
Review of 23 Years of Empirical Research on Information Technology Outsourcing Decisions and Outcomes
}

\author{
Professor Mary Lacity \\ University of Missouri-St. Louis \\ Mary.Lacity@umsl.edu
}

\author{
Dr. Aihua Yan \\ City University Hong Kong \\ aihuayan@cityu.edu.hk
}

\author{
Dr. Shaji Khan \\ University of Missouri-St. Louis \\ shajikhan@umsl.edu
}

\begin{abstract}
The 2010 Journal of Information Technology article, "A Review of the IT Outsourcing Empirical Literature," analyzed 741 empirical findings on the determinants of Information Technology Outsourcing (ITO) decisions and outcomes published between 1992 and 1st quarter 2010. In this paper, we replicated the method and coded additional findings published until the end of 2014. Combining the Lacity et al. (2010) with the additional findings, we used a total of 1,170 findings to produce the most robust models on ITO decisions and outcomes to date. The model of ITO decisions includes independent variables associated with transaction attributes, outsourcing motivations, influence sources, client characteristics and capabilities, relationship characteristics, and environmental variables. The model of ITO outcomes includes independent variables associated with transaction attributes, relational and contractual governance, client and provider capabilities, client characteristics and decision characteristics. The models serve as solid foundations for researchers seeking to advance academic contributions based on strong empirical data.
\end{abstract}

\section{Introduction}

Information technology (IT) sourcing is the sourcing of IT services, including application development, application support, systems integration, data management, data center management, telecommunications and network management, and distributed computing services. In its simplest conceptualization, an IT sourcing decision entails the fundamental "make or buy" decision [38], which results in insourcing or outsourcing of IT services. In reality, sourcing options are more complex; IT sourcing decisions may result in several types of "make" decisions, including insourcing to the internal IT function, creating shared IT services across organizational units, offshoring to a client-owned captive center, or bringing a previously outsourced IT service back in-house, i.e., backsourcing [6][26][27][31][37]. IT sourcing decisions may result in several types of "buy" decisions by outsourcing to a domestic provider, outsourcing to an offshore provider, multi-sourcing to several providers, outsourcing to a rural-based provider, or outsourcing to an impact sourcer, i.e., a sourcing provider with a social mission to train and employ people from marginalized populations [7][23][30][36]. In its simplest conceptualization, IT sourcing outcomes result in "success" or "failure". In reality, outcomes are multifaceted and include outcomes associated with organizational performance, strategic enablement of business objectives, IT costs, service quality, service responsiveness, scalability, and user satisfaction, to name common outcome measures [1][2][11][13] [21][33].

During the last few decades, researchers have dealt with this complexity by examining all types of IT sourcing decisions and outcomes. There is great value in conducting a literature review that finds a succinct way to summarize findings across studies, and indeed prior literature reviews summarized the ITO research in terms of research methods used [9], theories used [9][25], critical success factors [12], and the most influential articles and researchers [3]. The most comprehensive review of empirical findings was published in Lacity et al. [18]. The authors analyzed 741 empirical findings on the determinants of ITO decisions and outcomes from 164 quantitative and qualitative articles published between 1992 and 1st quarter of 2010. The authors developed two models based on the findings. One model identified 14 determinants of ITO decisions and the other model identified 25 determinants of ITO outcomes. But since Lacity et al. [18], many other scholars have continued to study ITO decisions and outcomes, prompting two research questions:

- What has the recent empirical academic literature found about the determinants of IT sourcing decisions and ITO outcomes?

- How do recent findings compare with previous findings?

To answer the questions, we updated Lacity et al. [18] by adding to the two models the empirical findings published where their data collection left off, through to the end of 2014. In this update, we examined new empirical IT sourcing articles across 66 academic journals. The updated models now include 22 determinants of ITO decisions and 29 determinants of ITO outcomes. Bringing the models up to date will 
help researchers by providing a comprehensive and current set of empirical findings to serve as a launch pad for further research.

\section{Research method}

We followed the method used in Lacity et al. [18], which was also used in [17][19][20][34] to find publications, code, analyze, and present findings.

\subsection{Finding Publications}

We conducted keyword searches in the ABI Inform, EBSCOHost, JSTOR, and Science Direct databases restricting the publication dates to be within the year 2010 and after. Through cursory examination of many hundreds of search results, we identified an initial pool of hundreds of journal articles. We eliminated articles which did not directly pertain to IT sourcing, were not empirical, or were considered in the previous JIT review. Thus, this review is based on 93 additional articles published in 66 refereed journals. Across all years (1992 to 2014), the most frequent outlets were the Journal of Management Information Systems with 16 empirical articles, Information \& Management (15 articles), MIS Quarterly (13 articles), Information Systems Research (11 articles) and Sloan Management Review (11 articles). ${ }^{1}$

\subsection{Coding variables and relationships}

We first created a relational database of the 93 articles. For each article, we extracted any relationship between an independent variable (IV) and a dependent variable (DV) associated with IT sourcing. In total, we had 429 relationships between an IV and a DV. In order to aggregate findings across studies and to abstract the particular variables used within studies at a higher level, we drew upon master codes of 150 variables used in Lacity et al. [18] as well as the updated version of the 219 codes published in Lacity et al. [19].

Following [17][18][19][20][34], we coded the nature of the relationships between study IV and DV variables as follows. A positive "significant" relationship was coded as " +1 ", a negative relationship was coded as "-1", a "not significant" relationship was coded as " 0 ". If the study was quantitative, we used $p$ $<0.05$ as the requirement for a significant positive or negative relationship. If the study was qualitative, we

\footnotetext{
${ }^{1}$ Contact the second author for the full table of 66 journals that shows the number of articles published in each journal by year, which is not included due to page limitations.
}

relied on the authors' strong arguments for a significant positive or negative relationship. For example, the authors of two case studies found that firms outsource and multisource "to expand their supply bases in order to keep exploring new supplier capabilities" [23] p. 727. We coded this finding as "access to skills and expertise" as positively related to "outsourcing decision" as indicated by a "+1".

The code " $M$ " was used to indicate a relationship that "mattered". The "M" code was needed because some significant relationships were categorical (i.e., not ordinal, interval, or continuous), but a relationship clearly mattered between the independent and dependent variable. For example, Langer et al. [19] found that project type (maintenance vs. new development) had significantly different effects on offshoring project success in terms of client satisfaction. The relationship between transaction type and offshore outsourcing success was therefore coded as "M" for "mattered".

The scheme allows for the coding of both qualitative and quantitative empirical findings. Table 1 summarizes the coding schema. The three authors coded articles individually and met weekly to discuss their codes. Once consensus was achieved for each IV, $\mathrm{DV}$, and the relationship between them, we recorded that relationship into our master database. After the first round of coding was completed, the third author then manually examined the codes to identify inconsistent codes and/or data entry errors. Any issues raised were resolved with input from all authors.

\section{Table 1. Coding schema for relationships}

\begin{tabular}{|l|c|l|}
\hline Relationship & Code & Meaning \\
\hline $\begin{array}{l}\text { Significant: } \\
\text { only } \mathrm{p}<.05 \\
\text { for } \\
\text { quantitative } \\
\text { studies or } \\
\text { strong } \\
\text { argument by } \\
\text { authors for } \\
\text { qualitative } \\
\text { studies coded } \\
\text { as significant }\end{array}$ & +1 & $\begin{array}{l}\text { Positive relationship between } \\
\text { independent variable (IV) and } \\
\text { dependent variable (DV). }\end{array}$ \\
\cline { 2 - 3 } & -1 & $\begin{array}{l}\text { Negative relationship } \\
\text { IV and a DV mattered }\end{array}$ \\
\hline $\begin{array}{l}\text { Not } \\
\text { significant }\end{array}$ & 0 & $\begin{array}{l}\text { Relationship was studied and no } \\
\text { significant relationship was found. }\end{array}$ \\
\hline \multicolumn{2}{|l|}{ Source: Lacity et al. [18][20][19] } \\
\hline
\end{tabular}

\subsection{Aggregating data with Lacity et al. (2010)}

We added the 429 coded relationships to the 741 coded relationships in Lacity et al. [18], bringing the total number of coded relationships to 1,170 empirical 
findings between an independent variable and a dependent variable. ${ }^{2}$ As with prior reviews, the relationships were sorted by DV type, either ITO decision or ITO outcome. The full data set comprises 540 relationships pertaining to ITO decisions and 630 relationships pertaining to ITO outcomes.

\subsection{Identifying major determinants of ITO decisions and outcomes}

We next followed the decision rules from prior reviews to extract the most robust findings of IVs that have been repeatedly examined and produced consistent results $[17][18][19][20]$. In terms of multiple examinations, we replicated the decision rule to extract the relationships that have been examined by researchers at least five times. In terms of consistent results, we also replicated the decision rule to extract variables in which at least $60 \%$ of the evidence was consistent. This minimum threshold ensures that more than half the evidence produced the same finding. We used the same tiered legend to further identify the level of consistent results as was used in [17][18][19][20]. Double symbols (++, --, MM, $00)$ indicate when more than 80 percent of the findings were consistent. Single symbols $(+,-, \mathrm{M}, 0)$ indicate when more than 60 percent and up to 80 percent of the findings were consistent. To be clear, double symbols indicate greater consistency among repeated findings across studies; they do not indicate the magnitude or strength of a particular relationship [19].

\section{Determinants of IT sourcing decisions}

Figure 1 depicts the empirical evidence that meets the criteria of at least 60 percent consistent findings from at least five examinations of a relationship between an independent variable and an IT sourcing decision. The figure captures 22 independent variables that affected IT sourcing decisions, organized by the seven broad categories of transaction attributes, motives to outsource, influence sources, client firm characteristics, client firm capabilities, relationship characteristics, and environment variables. This updated model of the determinants of IT sourcing decisions uncovered nine additional independent variables in comparison to Lacity et al. [18]. These new variables are indicated by an asterisk in the figure. "ITO Decision" signifies dependent variables associated with decisions to outsource. Thus, a positive relationship between an IV and ITO decision in Figure 1 means that the IV was positively related to

\footnotetext{
${ }^{2}$ Contact the second author for a large table of the 1,170 findings.
}

"outsourcing" decisions of some kind (domestic outsourcing, offshore outsourcing, multisourcing, rural sourcing, or impact sourcing). A negative relationship between an IV and ITO decisions means that the IV was negatively related to outsourcing or positively related to "insourcing" decisions of some kind (insourcing to an internal IT function, internal IT shared services, client-owned offshore captive centers, or backsourcing).

Table 2 provides the definitions of the IVs from Lacity et al. [18][19] $]^{3}$, the consistent relationship found between the IV and ITO decision (i.e., positive, negative, "mattered", or insignificant), and the number of times the consistent relationship was found divided by the total number of empirical examinations. The ratios were converted to percentages to show that each finding was at or above the 60 percent threshold of consistency. As an example of how to interpret the data in Table 2, the row entry on "Critical role of IS" indicates that the IV was examined 17 times and 12 times it was found to be negatively associated with outsourcing decisions or positively associated with insourcing decisions. The empirical replications were $71 \%$ consistent (12/17), exceeding the minimum threshold of $60 \%$.

\section{Determinants of ITO outcomes}

As noted in the introduction, ITO researchers have examined a plethora of ITO outcomes. The most frequently studied dependent variables in this category include outcomes that capture a client's general perceptions of the success or level of satisfaction with outsourcing (examined 47 times) and offshoring (examined 32 times). ITO researchers have studied the effects of outsourcing on a client organization's business performance (examined 27 times). Researchers have generally studied ITO outcomes using four units of analysis - the organization, the IS function, the client and supplier relationship, and the project. Although measures and units of analysis vary across studies, by aggregating the consequences of outsourcing to a single DV, we can conclude that any independent variable that consistently and repeatedly found a positive association with ITO outcomes, produced "better" results.

\footnotetext{
${ }^{3}$ Please note the definitions in Tables $2 \& 3$ from Lacity et al. [18][19] are missing several sources for each variable definition that cannot be included in this paper due to space limitations. Please refer to [18][19] for full citation credits.
} 


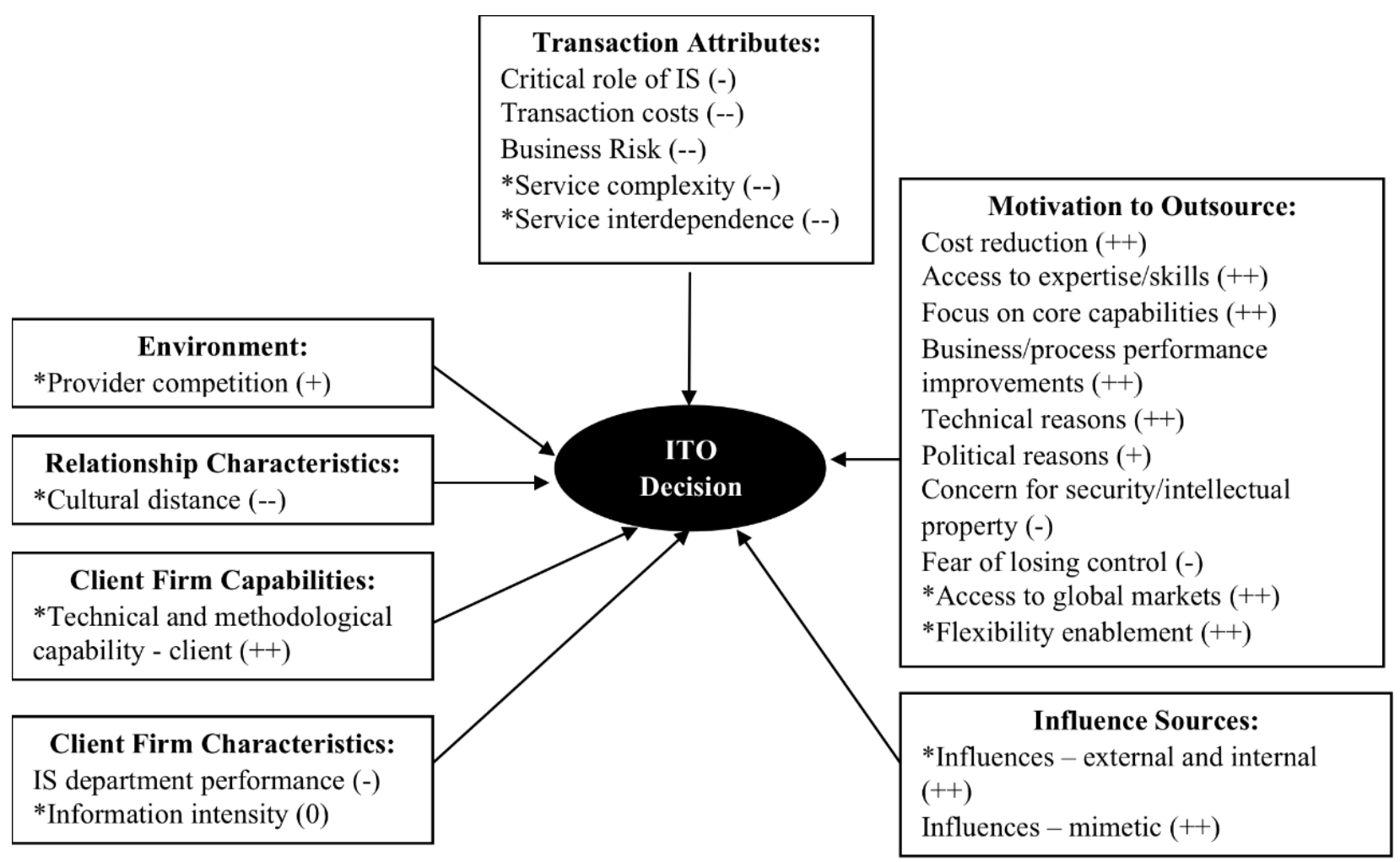

\section{Legend:}

* New variables since previous Lacity et al. (2010) ITO review

More than $80 \%$ of the evidence was positively significant $(++)$, negatively significant (--), not significant (00), or mattered (MM) $60 \%$ to $80 \%$ of the evidence was positively significant (+), negatively significant (-), not significant, or mattered (M)

Figure 1. Determinants of ITO decisions 
Table 2. Determinants of ITO decisions: Definitions and consistency of results

\begin{tabular}{|c|c|c|c|c|}
\hline $\begin{array}{l}\text { IV } \\
\text { Category }\end{array}$ & Definitions from Lacity et al. (2010; 2016) & $\begin{array}{c}\text { Consistent } \\
\text { relationship } \\
\text { to ITO } \\
\text { decision }\end{array}$ & $\begin{array}{l}\text { \# of consistent } \\
\text { findings/\# of } \\
\text { examinations }\end{array}$ & $\begin{array}{c}\% \\
\text { consistent }\end{array}$ \\
\hline \multirow{5}{*}{$\begin{array}{l}\text { Transaction } \\
\text { attributes }\end{array}$} & $\begin{array}{l}\text { Critical role of IS: "the degree to which a client organization views the IS } \\
\text { service as a critical enabler of business success." }\end{array}$ & Negative & $12 / 17$ & $71 \%$ \\
\hline & $\begin{array}{l}\text { Transaction costs: "the effort, time, and costs incurred to search, create, } \\
\text { negotiate, monitor, and administrate an IT services contract between a client } \\
\text { and provider." }\end{array}$ & Negative & $11 / 13$ & $85 \%$ \\
\hline & $\begin{array}{l}\text { Business risk: "the probability than an action will adversely affect an } \\
\text { organization." }\end{array}$ & Negative & $4 / 5$ & $80 \%$ \\
\hline & $\begin{array}{l}\text { Service complexity: "the degree to which a service or project requires } \\
\text { compound steps, the control of many variables, and/or where cause and } \\
\text { effect are subtle and dynamic." }\end{array}$ & Negative & $5 / 6$ & $83 \%$ \\
\hline & $\begin{array}{l}\text { Service interdependence: "the level of integration and coupling among } \\
\text { tasks; services that are highly integrated are tightly coupled and difficult to } \\
\text { detach." }\end{array}$ & Negative & $5 / 5$ & $100 \%$ \\
\hline \multirow{10}{*}{$\begin{array}{l}\text { Motivations } \\
\text { to outsource }\end{array}$} & $\begin{array}{l}\text { Cost reduction: "a client organization's need or desire to reduce the costs of } \\
\text { providing an IT service." }\end{array}$ & Positive & $47 / 50$ & $94 \%$ \\
\hline & $\begin{array}{l}\text { Access to expertise/skills: "client organization's desire or need to access } \\
\text { provider skills / expertise." }\end{array}$ & Positive & $23 / 25$ & $92 \%$ \\
\hline & $\begin{array}{l}\text { Focus on core capabilities: "A client organization's desire or need to focus } \\
\text { its resources on its core capabilities." }\end{array}$ & Positive & $23 / 25$ & $92 \%$ \\
\hline & $\begin{array}{l}\text { Business/process performance improvement: "a client organization's } \\
\text { desire or need to improve the performance of the client's business, processes, } \\
\text { or capabilities". }\end{array}$ & Positive & $18 / 18$ & $100 \%$ \\
\hline & $\begin{array}{l}\text { Technical reasons: "a client's desire or need to gain access to leading edge } \\
\text { technology." }\end{array}$ & Positive & $10 / 10$ & $100 \%$ \\
\hline & $\begin{array}{l}\text { Political reasons: "a client's desire to use an outsourcing decision to } \\
\text { promote a personal agenda." }\end{array}$ & Positive & $5 / 8$ & $63 \%$ \\
\hline & $\begin{array}{l}\text { Concern for Security/Intellectual Property: "a client organization's } \\
\text { concerns about security of information, transborder data flow issues, and } \\
\text { protection of intellectual property." }\end{array}$ & Negative & $5 / 7$ & $71 \%$ \\
\hline & Fear of losing control over the IT service. & Negative & $7 / 9$ & $78 \%$ \\
\hline & $\begin{array}{l}\text { Access to global markets: "A client organization's desire or need to gain } \\
\text { access to global markets." }\end{array}$ & Positive & $6 / 6$ & $100 \%$ \\
\hline & $\begin{array}{l}\text { Flexibility enablement: "a client organization's desire or need to increase } \\
\text { the flexibility of the use and allocation of resources for IT services." }\end{array}$ & Positive & $6 / 6$ & $100 \%$ \\
\hline \multirow{2}{*}{$\begin{array}{l}\text { Influence } \\
\text { sources }\end{array}$} & $\begin{array}{l}\text { External and internal influences: "the combination of external media, } \\
\text { provider pressure, and internal communications at the personal level among } \\
\text { manager(s) in charge of a sourcing decision." }\end{array}$ & Positive & $5 / 6$ & $83 \%$ \\
\hline & $\begin{array}{l}\text { Mimetic influences: "arise from the perception that peer organizations are } \\
\text { more successful; by modeling behavior based on peer behavior, the } \\
\text { mimicking organization aims to achieve similar results." }\end{array}$ & Positive & $4 / 5$ & $80 \%$ \\
\hline \multirow{2}{*}{$\begin{array}{l}\text { Client firm } \\
\text { character- } \\
\text { istics }\end{array}$} & $\begin{array}{l}\text { Prior IS department performance: "the performance of the IS department } \\
\text { before or during an outsourcing decision, typically measured as an } \\
\text { organizational members' perceptions of the IT function's performance or } \\
\text { competence in the past." }\end{array}$ & Negative & $11 / 16$ & $69 \%$ \\
\hline & $\begin{array}{l}\text { Information intensity: "an indicator of whether a client organization is IT } \\
\text { intensive, as measured, for example, by IT budget as a percentage of } \\
\text { revenues." }\end{array}$ & $\begin{array}{c}\text { Not- } \\
\text { significant }\end{array}$ & $4 / 6$ & $67 \%$ \\
\hline $\begin{array}{l}\text { Client firm } \\
\text { capabilities }\end{array}$ & $\begin{array}{l}\text { Technical and methodological capability - client: "a client organization's } \\
\text { level of maturity in terms of technical or process related standards and best } \\
\text { practices." }\end{array}$ & Positive & $5 / 5$ & $100 \%$ \\
\hline $\begin{array}{c}\text { Relationship } \\
\text { character- } \\
\text { istics }\end{array}$ & $\begin{array}{l}\text { Cultural distance: "the extent to which the members of two distinct groups } \\
\text { differ on one or more cultural dimensions." }\end{array}$ & Negative & $4 / 5$ & $80 \%$ \\
\hline Environment & $\begin{array}{l}\text { Provider competition: "the presence of multiple, reputable and trustworthy } \\
\text { service providers which can provide a range of choices for the clients." }\end{array}$ & Positive & $4 / 6$ & $67 \%$ \\
\hline
\end{tabular}


Figure 2 depicts the empirical evidence that meets the criteria of at least 60 percent consistent findings from at least five examinations of a relationship between an independent variable and an IT outsourcing outcome. We are only examining the effects of outsourcing decisions, not the effects of insourcing decisions. The figure captures 29 independent variables that affected ITO outcomes, organized by the seven broad categories of transaction attributes, relational governance, contractual governance, client and provider firm capabilities, client firm characteristics, and decision characteristics. This updated model of the determinants of ITO outcomes uncovered nine additional independent variables, indicated by an asterisk in Figure 2.

Table 3 provides the definitions of the IVs from Lacity et al. [18][19], the consistent relationship found between the IV and ITO outcomes (i.e., positive, negative, "mattered", or insignificant), and the number of times the consistent relationship was found divided by the total number of empirical examinations. The ratios were converted to percentages to show that each finding was at or above the 60 percent threshold of consistency. As an example of how to interpret the data in Table 3, the row entry on indicates that the IV "uncertainty" was examined 20 times and 14 times it was found to be negatively associated with outsourcing outcomes. The empirical replications were $70 \%$ consistent $(14 / 17)$, exceeding the minimum threshold of $60 \%$.

\section{Discussion}

\subsection{Determinants of ITO decisions}

On the determinants of ITO decisions, the empirical evidence found that sourcing decisions were complex as demonstrated by the 22 significant independent variables that were empirically found to repeatedly influence ITO decisions across the seven broad categories. Cost savings was a major determinant of ITO decisions, consistent with transaction cost economics [39], but client organizations clearly had a rich set of motives driving sourcing decisions in addition to cost savings, including the desire to improve the business/process performance and flexibility of existing services, the desire to access a provider's expertise, technical assets and global markets, and a strategy to focus in-house staff on core capabilities (e.g. [35]). When clients feared losing control over the IT service or feared loss of security and intellectual property, they tended to select insourcing options. Some sourcing decisions were also motivated by political agendas (e.g., [15]). When making sourcing decisions, client organizations tended to keeping critical IS services in-house.

Client organizations also considered a number of other transaction attributes that hindered outsourcing and favored insourcing, including high transaction costs, high business risks, high service complexity, and high service interdependence (e.g., [29]). 


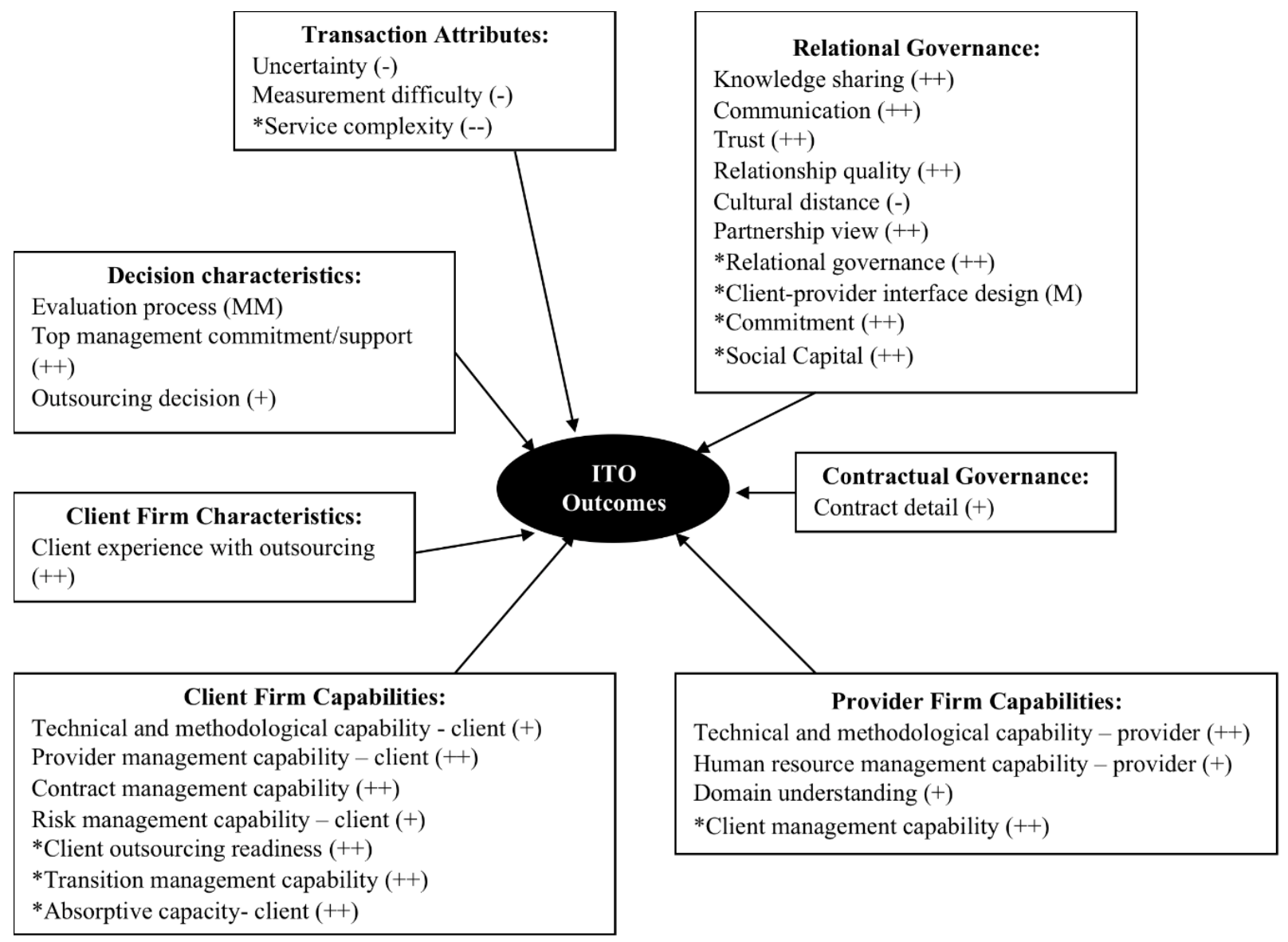

Legend:

* New variables since previous Lacity et al. (2010) ITO review

More than $80 \%$ of the evidence was positively significant (++), negatively significant (--), not significant (00), or mattered (MM)

$60 \%$ to $80 \%$ of the evidence was positively significant $(+)$, negatively significant (-), not significant, or mattered (M)

Figure 2. Determinants of ITO outcomes

Table 3. Determinants of ITO outcomes: Definitions and consistency of results

\begin{tabular}{|c|c|c|c|c|}
\hline $\begin{array}{c}\text { IV } \\
\text { Category }\end{array}$ & Definitions from Lacity et al. (2010; 2016) & $\begin{array}{l}\text { Consistent } \\
\text { relationship } \\
\text { to ITO } \\
\text { decision }\end{array}$ & $\begin{array}{c}\text { \# of } \\
\text { consistent } \\
\text { findings/\# } \\
\text { of } \\
\text { examinati } \\
\text { ons } \\
\end{array}$ & $\begin{array}{c}\% \\
\text { con- } \\
\text { sistent }\end{array}$ \\
\hline \multirow{3}{*}{$\begin{array}{c}\text { Transaction } \\
\text { attributes }\end{array}$} & $\begin{array}{l}\text { Uncertainty: "the degree of unpredictability or volatility of future states as it } \\
\text { relates to the definition of requirements, emerging technologies, and/or } \\
\text { environmental factors." }\end{array}$ & Negative & $14 / 20$ & $70 \%$ \\
\hline & $\begin{array}{l}\text { Measurement difficulty: "the degree of difficulty in measuring performance } \\
\text { of exchange partners in circumstances of joint effort, soft outcomes, and/or } \\
\text { ambiguous links between effort and performance." }\end{array}$ & Negative & $6 / 9$ & $67 \%$ \\
\hline & $\begin{array}{l}\text { Service complexity: "the degree to which a service or project requires } \\
\text { compound steps, the control of many variables, and/or where cause and effect } \\
\text { are subtle and dynamic." }\end{array}$ & Negative & $4 / 5$ & $80 \%$ \\
\hline $\begin{array}{c}\text { Relational } \\
\text { governance }\end{array}$ & $\begin{array}{l}\text { Knowledge sharing: "the degree to which clients and providers share and } \\
\text { transfer knowledge." }\end{array}$ & Positive & $21 / 23$ & $91 \%$ \\
\hline
\end{tabular}




\begin{tabular}{|c|c|c|c|c|}
\hline $\begin{array}{l}\text { IV } \\
\text { Category }\end{array}$ & Definitions from Lacity et al. $(2010 ; 2016)$ & $\begin{array}{l}\text { Consistent } \\
\text { relationship } \\
\text { to ITO } \\
\text { decision }\end{array}$ & $\begin{array}{c}\text { \# of } \\
\text { consistent } \\
\text { findings/\# } \\
\text { of } \\
\text { examinati } \\
\text { ons } \\
\end{array}$ & $\begin{array}{c}\% \\
\text { con- } \\
\text { sistent }\end{array}$ \\
\hline & $\begin{array}{l}\text { Communication: "the degree to which parties are willing to openly discuss } \\
\text { their expectations, directions for the future, their capabilities, and/or their } \\
\text { strengths and weaknesses." }\end{array}$ & Positive & $14 / 14$ & $100 \%$ \\
\hline & Trust: "the confidence in the other party's benevolence." & Positive & $13 / 16$ & $81 \%$ \\
\hline & $\begin{array}{l}\text { Relationship quality: "the quality of the relationship between a client and } \\
\text { provider." }\end{array}$ & Positive & $5 / 6$ & $83 \%$ \\
\hline & $\begin{array}{l}\text { Cultural distance: "the extent to which the members of two distinct groups } \\
\text { differ on one or more cultural dimensions." }\end{array}$ & Negative & $7 / 9$ & $78 \%$ \\
\hline & $\begin{array}{l}\text { Partnership view: "a client organization's consideration of a provider as a } \\
\text { trusted partner rather than as an opportunistic vendor." }\end{array}$ & Positive & $5 / 6$ & $83 \%$ \\
\hline & $\begin{array}{l}\text { Relational governance: "the unwritten, worker-based mechanisms designed } \\
\text { to influence inter-organizational behavior." }\end{array}$ & Positive & $9 / 11$ & $82 \%$ \\
\hline & $\begin{array}{l}\text { Client-provider interface design: "the planned structure on where, when, } \\
\text { and how client and provider employees work, interact, and communicate." }\end{array}$ & Mattered & $6 / 8$ & $75 \%$ \\
\hline & $\begin{array}{l}\text { Commitment: "the degree to which partners pledge to continue the } \\
\text { relationship." }\end{array}$ & Positive & $5 / 5$ & $100 \%$ \\
\hline & $\begin{array}{l}\text { Social capital: "the sum of the actual and potential resources embedded } \\
\text { within, available through, and derived from the network of relationships." }\end{array}$ & Positive & $4 / 5$ & $80 \%$ \\
\hline $\begin{array}{l}\text { Contractual } \\
\text { governance }\end{array}$ & $\begin{array}{l}\text { Contract detail: "the number or degree of detailed clauses in the outsourcing } \\
\text { contract, such as clauses that specify prices, service levels, key process } \\
\text { indicators, benchmarking, warranties, and penalties for non-performance." }\end{array}$ & Positive & $15 / 19$ & $79 \%$ \\
\hline \multirow{4}{*}{$\begin{array}{l}\text { Provider firm } \\
\text { capabilities }\end{array}$} & $\begin{array}{l}\text { Technical and methodological capability - provider: "a provider } \\
\text { organization's level of maturity in terms of technical or process related and } \\
\text { best practices." }\end{array}$ & Positive & $15 / 17$ & $88 \%$ \\
\hline & $\begin{array}{l}\text { Human resource management capability - provider: "a provider } \\
\text { organization's ability to identify, acquire, develop, retain, and deploy human } \\
\text { resources to achieve both provider's and client's organizational objectives." }\end{array}$ & Positive & $12 / 16$ & $75 \%$ \\
\hline & $\begin{array}{l}\text { Domain understanding: "the extent to which a provider has prior experience } \\
\text { and/or understanding of the client organization's business and technical } \\
\text { contexts, processes, practices, and requirements." }\end{array}$ & Positive & $4 / 6$ & $67 \%$ \\
\hline & $\begin{array}{l}\text { Client management capability: "the extent to which a provider organization } \\
\text { is able to effectively manage client relationships." }\end{array}$ & Positive & $9 / 9$ & $100 \%$ \\
\hline \multirow{7}{*}{$\begin{array}{l}\text { Client firm } \\
\text { capabilities }\end{array}$} & $\begin{array}{l}\text { Technical and methodological capability - client: "a client organization's } \\
\text { level of maturity in terms of technical or process related standards and best } \\
\text { practices". }\end{array}$ & Positive & $9 / 12$ & $75 \%$ \\
\hline & $\begin{array}{l}\text { Provider management capability: "the extent to which a client organization } \\
\text { is able to effectively manage outsourcing providers." }\end{array}$ & Positive & $14 / 14$ & $100 \%$ \\
\hline & $\begin{array}{l}\text { Contract management capability - client: "the extent to which a client } \\
\text { organization is able to effectively prepare, negotiate and manage contracts } \\
\text { with providers, including the ability to track service levels and verify } \\
\text { invoices." }\end{array}$ & Positive & $11 / 11$ & $100 \%$ \\
\hline & $\begin{array}{l}\text { Risk management capability - client: "a client organization's practice of } \\
\text { identifying, rating, and mitigating potential risks associated with } \\
\text { outsourcing." }\end{array}$ & Positive & $5 / 7$ & $71 \%$ \\
\hline & $\begin{array}{l}\text { Client outsourcing readiness: "the extent to which a client organization is } \\
\text { prepared to engage an outsourcing provider by having realistic expectations } \\
\text { and a clear understanding of internal costs and services compared to } \\
\text { outsourced costs and services." }\end{array}$ & Positive & $12 / 12$ & $100 \%$ \\
\hline & $\begin{array}{l}\text { Transition management capability - client: "the extent to which a client } \\
\text { organization effectively transitions services to or from outsourcing providers } \\
\text { or integrates client services with provider services." }\end{array}$ & Positive & $6 / 6$ & $100 \%$ \\
\hline & $\begin{array}{l}\text { Absorptive capacity - client: "a client organization's ability to scan, acquire, } \\
\text { assimilate, and exploit valuable knowledge." }\end{array}$ & Positive & $4 / 5$ & $80 \%$ \\
\hline
\end{tabular}




\begin{tabular}{|c|l|c|c|}
\hline \multirow{2}{*}{$\begin{array}{c}\text { IV } \\
\text { Category }\end{array}$} & \multicolumn{1}{c|}{$\begin{array}{c}\text { Consistent } \\
\text { Definitions from Lacity et al. (2010; 2016) }\end{array}$} & $\begin{array}{c}\# \text { of } \\
\text { relationship } \\
\text { to ITO } \\
\text { decisionsistent } \\
\text { findings/\# } \\
\text { of } \\
\text { examinati } \\
\text { ons }\end{array}$ & $\begin{array}{c}\text { \%on- } \\
\text { sistent }\end{array}$ \\
\hline $\begin{array}{c}\text { Client firm } \\
\text { characteristics }\end{array}$ & $\begin{array}{l}\text { Client experience with outsourcing: "the situation in which the client has } \\
\text { prior outsourcing experience." }\end{array}$ & Positive & $5 / 6$ \\
\hline \multirow{2}{*}{$\begin{array}{c}\text { Decision } \\
\text { characteristics }\end{array}$} & $\begin{array}{l}\text { Evaluation process: "the client organization's process for evaluating and } \\
\text { selecting providers." For example, whether bids were solicited, whether a } \\
\text { consulting firm was hired to help, or the number of bids received. }\end{array}$ & Mattered & $7 / 8$ \\
\cline { 2 - 5 } & $\begin{array}{l}\text { Top management commitment / support: "the extent to which senior } \\
\text { executives provide leadership, support, and commitment to outsourcing." }\end{array}$ & Positive & $68 \%$ \\
\cline { 2 - 5 } & $\begin{array}{l}\text { Outsourcing decision: "a client organization's decision to engage a provider } \\
\text { for IT services." }\end{array}$ & Positive & $7 / 6$ \\
\hline
\end{tabular}

Clients were clearly influenced by both external and internal influences when making sourcing decisions (e.g., [4]). From the theory of institutional isomorphism [10], mimetic influences were the only influence source that was repeatedly examined and found to positively affect ITO decisions; coercive and normative influences were only studied once, so more examinations are needed.

CIOs are also warned that their department's past performance will likely influence sourcing decisions, with poor performers more likely to be outsourced than high performers. Client firm capabilities also influenced sourcing decisions. Clients felt more confident in outsourcing services when they themselves had mature technical and methodological capabilities. This finding seems to contradict the finding that client firms outsourced for "technical reasons", but maturity is related to processes, not specific technologies. Repeated tests of one client firm characteristic, namely information intensity, resulted in no significant results, indicating information intensity is not a determinant of ITO decisions using our rules. We included it in Figure 1 to signal to other researchers that this may not be a fruitful IV for further investigation.

When considering which provider to source a service, client organizations tended to shy away from providers that were perceived as being culturally distant from the client organization. Clients were also more likely to outsource when they perceived a healthy level of provider competition, perhaps to pressure prices or to ease switching providers if the incumbent performs poorly.

\subsection{Determinants of ITO outcomes}

On the determinants of ITO outcomes, the empirical evidence suggested that sourcing outcomes were also complex as demonstrated by the 29 significant independent variables that were found repeatedly to influence ITO outcomes across seven broad categories.

Across the studies, clients struggled to get good sourcing outcomes under conditions of high uncertainty, high measurement difficulty and for IT services that were complex.

Relational governance as a broad category powerfully influenced ITO outcomes (e.g., [24]). Higher levels of eight relational governance variables were associated with better sourcing outcomes: knowledge sharing, communication, trust, relationship quality, partnership view, relational governance (generic IV), commitment, and social capital (e.g., [14][32]). The interface design also mattered - clients and providers need to actively design how the parties work together. Cultural distance hurt ITO outcomes, but this, in theory, could be offset with higher levels of a cultural distance management capability [19].

As far as contractual governance, client organizations that signed detailed contracts reported better ITO outcomes than clients that signed loose contracts.

Capabilities were also important determinants of ITO outcomes (e.g., [16][22][28]). Providers with strong technical and methodological, HR management, domain understanding, and client management capabilities produced better outcomes for clients and for themselves compared to providers with weak capabilities. Clients with strong technical and methodological, provider management, contract management, risk management, transition management and absorptive capacity capabilities had better ITO outcomes compared to clients with weak or immature capabilities (e.g., [5]).

Clients needed to be ready to outsource by having realistic expectations and a clear understanding of internal costs and services compared to outsourced 
costs and services. Prior IT outsourcing experience of clients was associated with better outcomes. The way clients made ITO decisions also mattered in that the provider evaluation process and top management support affected ITO outcomes (e.g., [8]). Finally, we report that client organizations that decided to outsource IT services reported positive outcomes in 63 percent of findings.

\subsection{Research limitations}

This current review and Lacity et al. [18] share the same limitations since they followed the same method. First, the relationships in both reviews only capture direct effects, not interactive effects or dynamic effects. Second, the review method is not as statistically rigorous as a meta-analysis but it is richer in that the review considers empirical results from both qualitative and quantitative studies. Among the 257 articles in the entire combined data set, 118 are qualitative studies. Third, the selected threshold values for analyzing repeated relationships of five times or more and extracting consistent findings of greater than 60 percent are arbitrary. We used these thresholds to compare findings with prior reviews. The detailed data is available from the second author upon request if researchers want to rerun analyses using different decision rules.

\subsection{Future research opportunities}

This review succinctly collapsed the myriad of dependent variables used in ITO research to just two variables: ITO decision and ITO outcome. A similar normalization of the independent variables would help develop more parsimonious models of the determinants of ITO decisions and ITO outcomes. For example, many of the Relational Governance variables may be reasonably combined to yield a smaller set. In addition Lacity et al. [19] provide detailed suggestions for future research.

\section{Conclusion}

This review of the empirical IT sourcing literature aimed to succinctly summarize a vast body of research on the determinants of IT sourcing decisions and outcomes. We expanded upon the Lacity et al. (2010) review to now include a total of 1,170 empirical examinations of the relationships between independent and dependent variables. This broadened review highlights new independent variables of interest as well as presents variables that have remained relevant. The models of the determinants of ITO decisions and outcomes may be used to guide future research by pointing to significant variables of interest.

\section{References $^{4}$}

[1] Agarwal, M., Kishore, R. and Rao, H.R. (2006). Market Reactions to E-business Outsourcing Announcements: An event study, Information \& Management 43: 861-873.

[2] Agrawal, P. and Haleem, A. (2013). The Impact of the Outsourcing of IT on Firm Performance: An Empirical Study, International Journal of Management 30(3): 121-139.

[3] Alsuairi, M. and Dwivedi, Y. (2010). A multidisciplinary profile of IS/IT outsourcing research, Journal of Enterprise Information Management, 23(2):215-258.

[4] Ang, S. and Cummings, L. (1997). Strategic Response to Institutional Influences on Information Systems Outsourcing, Organization Science 8(3): 235-256.

[5] Beulen, E., Tiwari, V. and van Heck, E. (2011). Understanding Transition Performance During Offshore IT Outsourcing, Strategic Outsourcing: An International Journal 4(3): 204-227.

[6] Bhagwatwar, A., Hackney, R. and Desouza, K. C. (2011). Considerations for Information Systems "Backsourcing": A Framework for Knowledge ReIntegration, Information Systems Management 28(2): 165-173.

[7] Carmel, E., Lacity, M., and Doty, A. (2014), The Impact of Impact Sourcing: Framing a Research Agenda. In: Information Systems Outsourcing: Towards Sustainable Business Value, Hirschheim, R., Heinzl, A., and Dibbern, J. (eds.): 397-430.Springer, Heidelberg.

[8] Cullen, S., Seddon, P. and Willcocks, L. (2005). Managing Outsourcing: The life cycle imperative, MIS Quarterly Executive 4(1): 229-246.

[9] Dibbern, J., Goles, T., Hirschheim, R. and Jayatilaka, B. (2004). Information Systems Outsourcing: A Survey and Analysis of the Literature, ACM SIGMIS Database 35(4): 6-102.

[10] DiMaggio, P. and Powell, W. (1991). The Iron Cage Revisited: Institutional isomorphism and collective rationality in organizational fields, in P. Powell and W. DiMaggio (eds.) The New Institutionalism in Organizational Analysis, Chicago, IL: The University of Chicago Press: 63-82.

[11] DiRomualdo, A. and Gurbaxani, V. (1998). Strategic Intent for IT Outsourcing, Sloan Management Review 39(4): $67-80$.

\footnotetext{
${ }^{4}$ Due to space limitations, we could not include the citations for the articles coded in the review or provide sample articles that illustrated the determinants. Contact second author for a full set of 314 references used to inform this research.
} 
[12] Fjermestad, J. and Saitta, J. (2005). A Strategic Management Framework for IT Outsourcing: A review of the literature and the development of a success factors model, Journal of IT Case and Application Research 7(3): 42-60.

[13] Goo, J., Kishore, R., Rao, H.R. and Nam, K. (2009). The Role of Service Level Agreements in Relational Management of Information Technology Outsourcing: An empirical study, MIS Quarterly 33(1): 1-28.

[14] Gopal, A. and Koka, B. R. (2012). The Asymmetric Benefits of Relational Flexibility: Evidence from Software Development Outsourcing, MIS Quarterly 36(2): 553-576.

[15] Hall, J. and Liedtka, S. (2005). Financial Performance, CEO Compensation, and Large-Scale Information Technology Outsourcing Decisions, Journal of Management Information Systems 22(1): 193-222.

[16] Jarvenpaa, S. and Mao, J. (2008). Operational Capabilities Development in Mediated Offshore Software Service Models, Journal of Information Technology 23(1): 3-17.

[17] Jeyaraj, A., Rottman, J., and Lacity, M. (2006), “A Review of the Predictors, Linkages, and Biases in IT Innovation Adoption Research," Journal of Information Technology, 21(1): 1-23.

[18] Lacity, M. C., Khan, S., Yan, A. and Willcocks, L. P. (2010). A Review of the IT Outsourcing Empirical Literature and Future Research Directions, Journal of Information technology 25(4): 395-433.

[19] Lacity, M., Khan, S., and Yan, A. (2016), "Review of the Empirical Business Services Sourcing Literature: An Update and Future Directions," Journal of Information Technology, 31(2):1-60.

[20] Lacity, M. C., Solomon, S., Yan, A. and Willcocks, L. P. (2011). Business Process Outsourcing Studies: A Critical Review and Research Directions, Journal of information technology 26(4): 221-258.

[21] Lee, J., Miranda, S. and Kim, Y. (2004). IT Outsourcing Strategies: Universalistic, contingency, and configurational explanations of success, Information Systems Research 15(2): 110-131.

[22] Levina, N. and Ross, J. (2003). From the Vendor's Perspective: Exploring the value proposition in IT outsourcing, MIS Quarterly 27(3): 331-364.

[23] Levina, N. and Su, N. (2008). Global Multisourcing Strategy: The emergence of a supplier portfolio in services offshoring, Decision Sciences 39(3): 541-570.

[24] Lioliou, E., Zimmermann, A., Willcocks, L. and Gao, L. (2014). Formal and Relational Governance in IT Outsourcing: Substitution, Complementarity and the Role of the Psychological Contract, Information Systems Journal 24(6), 503-535.

[25] Mahnke, V., Overby, M.L. and Vang, J. (2005). Strategic Outsourcing of IT Services: Theoretical stocktaking and empirical challenges, Industry and Innovation 12(2): 205-253.

[26] McKeen, J. and Smith, H. (2011). Creating IT Shared Services, Communications of the AIS 29(34): 645-656.

[27] Oshri, I. and Van Uhm, B. (2012). A Historical Review of the Information Technology and Business
Process Captive Centre Sector, Journal of Information Technology 27(4): 270-284.

[28] Palvia, P., King, R., Xia, W. and Jain Palvia, S. (2010). Capability, Quality, and Performance of Offshore IS Vendors: A Theoretical Framework and Empirical Investigation, Decision Sciences 41(2): 231270.

[29] Poppo, L. and Zenger, T. (2002). Do Formal Contracts and Relational Governance Function as Substitutes or Complements? Strategic Management Journal 23: 707725.

[30] Poston, R., Simon, J. and Jain, Radhika. (2010). Client Communication Practices in Managing Relationships with Offshore Vendors of Software Testing Services, Communications of the AIS 27(9): 129-148.

[31] Qu, W. G., Oh, W. and Pinsonneault, A. (2010). The Strategic Value of IT Insourcing: An IT-Enabled Business Process Perspective, The Journal of Strategic Information Systems 19(2): 96-108.

[32] Sabherwal, R. (1999). The Role of Trust in Outsourced IS Development Projects, Communications of the ACM 42(2): 80-86.

[33] Saunders, C., Gebelt, M. and Hu, Q. (1997). Achieving Success in Information Systems Outsourcing, California Management Review 39(2): 63-80.

[34] Schneider, S. and Sunyaev, A. (2016), Determinant factors of cloud-sourcing decisions: reflecting on the IT outsourcing literature in the era of cloud computing, Journal of Information Technology, 31(1):1-31.

[35] Sia, S., Koh, C. and Tan, C. (2008). Strategic Maneuvers for Outsourcing Flexibility: An empirical assessment, Decision Sciences 39(3): 407-443.

[36] Su, N. and Levina, N. (2011). Global Multisourcing Strategy: Integrating Learning from Manufacturing into IT Service Outsourcing, IEEE Transactions on Engineering Management 58(4): 717-729.

[37] Veltri, N. F., Saunders, C. S. and Kavan, C. B. (2008). Information Systems Backsourcing: Correcting Problems and Responding To Opportunities, California Management Review 51(1), 50-76.

[38] Williamson, O. (1975). Markets and Hierarchies: Analysis and Antitrust Implications. Free Press, New York.

[39] Williamson, O. (1991). Comparative Economic Organization: The analysis of discrete structural alternatives, Administrative Science Quarterly, 36(2): 269-296. 